Penser les épidémies depuis la Chine, le Japon et la Corée

\title{
Epidemic Control and Wars in Republican China
} (1935-1955)

Contrôle des épidémies et guerres dans la Chine républicaine (1935-1955)

民國時期中國境内的戰爭與疫病控制(1935-1955)

\section{Michael Shiyung Liu}

\section{(2) OpenEdition}

\section{Journals}

Electronic version

URL: http://journals.openedition.org/extremeorient/335

DOI: 10.4000/extremeorient.335

ISSN: 2108-7105

\section{Publisher}

Presses universitaires de Vincennes

\section{Printed version}

Date of publication: 1 September 2014

Number of pages: 117-139

ISBN: 978-2-84292-411-9

ISSN: 0754-5010

Electronic reference

Michael Shiyung Liu, « Epidemic Control and Wars in Republican China (1935-1955) », Extrême-Orient Extrême-Occident [Online], 37 | 2014, Online since 01 September 2017, connection on 19 April 2019. URL : http://journals.openedition.org/extremeorient/335 ; DOI : 10.4000/extremeorient.335 


\title{
Epidemic Control and Wars in Republican China (1935-1955) ${ }^{1}$
}

\author{
Michael Shiyung Liu
}

During the second half of the 20th century, the US government and USbased NGOs more than doubled their funding of overseas medical programs, bringing it up to thirty percent of total foreign aid expenditure. There has, however, been little direct study of the role American medical aid has played in building the long-term security, stability, governance, or legitimacy of East Asian countries where adverse health conditions may affect US interests. This article sheds light on American medical aid to China in the turbulent decades of the Sino-Japanese War (1937-1945), the Chinese Civil War (1947-1949), and the subsequent scission of China into two political entities, when the Nationalist government had to face health problems directly linked to armed combat as well as epidemic diseases.

Epidemic control was not the leading priority during the Sino-Japanese War (1937-1945). The treatment of the epidemics that swept the country was largely overshadowed by health problems more directly linked to the war. However, the emergency measures and structures implemented during the war, and largely financed by American organizations, were the foundations for epidemic control in the post-war era. Between 1945 and 1952, plague and cholera were endemic throughout China, and over the same period it was estimated that more than one million people were infected with malaria. These "post-war" epidemics which were attributed to the destruction of quarantine systems as well as to the movement of refugees through the country had a serious impact on people's lives and hindered recovery projects put in place by local and regional authorities. ${ }^{2}$ Controlling these epidemics soon became

1. The research has been supported by the National Science Council of Taiwan projects NSC101-2410-H-001-022 and NSC99-2410-H-001-044-MY2.

2. Liu 2011. 
a common goal uniting Japanese-trained and American-influenced medical professionals in the country.

Drawing on archives from the Rockefeller Archive Center (New York), ${ }^{3}$ Academia Historica and the National Defense Medical Center (NDMC) in Taiwan, and Japan Diet Library, this article aims to portray the challenge of controlling epidemics during the early post-WWII period in China and of reconstructing epidemic control systems in Taiwan from 1949 onward. In addition to focusing on the post-WWII era, it traces the long-term cooperation between Nationalist China and US philanthropic organizations such as the American Bureau of Medical Aid to China (ABMAC) as well as the Rockefeller Foundation and its medical affiliate, the China Medical Board (CMB) prior to 1945. It also assesses the impact of the Nationalist Government's withdrawal to Taiwan on the rebuilding of epidemic prevention systems in mainland China and Taiwan.

\section{American medical aid in wartime China}

The motives for reestablishing a public health system in post-WWII China were twofold. One reason was the urgent need to prevent the return of epidemics as a result of long-term war damage. The other was to resume the efforts in public health modernization which had been interrupted by the 1937-1945 Sino-Japanese war. According to Yip Ka-che, the Americanoriented medical curriculum as well as the technical approaches of the Rockefeller Foundation were adopted by the majority of the health officials of the Nationalist government during the 1930s as a part of the public health modernization scheme. ${ }^{4}$ However, there were many obstructions to the ambitious scheme that Americans and the Nationalist government proposed. Yip shows that the agricultural economy was a significant hindrance to the project, since industrialization was a key factor in the development of the American public health system. ${ }^{5}$ Besides, to most historians of modern China,

3. A great deal of financial support and ideas to reform public health infrastructure in China were provided by the Rockefeller Foundation and its affiliate the China Medical Board. The Rockefeller Archive Center is a treasure for historians who are interested in finding primary documents on medical reform in Republican China. The Center also holds other resources on medical aid to China from the US thanks to the Foundation's central position in medical reform in China since the first decade of the 20th century.

4. Yip 1995.

5. Yip 1982: 1197-1205. 
the military conflict between Japan and China during the period was another major factor delaying the modernization efforts.

In mainland China, the Peking Union Medical College (PUMC) and the $\mathrm{CMB}$, both funded by the Rockefeller Foundation, had been major actors in transforming medical and public health systems since the first decade of the 20 th century. ${ }^{6}$ However, in response to the crisis caused by the escalating SinoJapanese war, expatriate Chinese and alumni from PUMC set up the American Bureau for Medical Aid to China (ABMAC), later the American Bureau for Medical Advancement in China. ABMAC was a philanthropic organization whose sole aim was to assist the medical modernization in wartime China.

The Japanese conquest of Manchuria in 1931 was only the first step in what became a much larger campaign to expand Japanese influence in Northern China, a campaign that resulted in full-scale war between Japan and China in 1937. The invasion of China proper began in earnest with "The North China Incident," a military clash that occurred between Chinese and Japanese troops in 1937 near Beiping (today's Beijing) in North China. Before "The North China Incident," the Defense of the Great Wall or Battle of Gubeikou (also known as "Operation Nekka" or "First Battle of Hopei") took place between January 1 and May 31, 1933 (Map 1). ${ }^{7}$ Gubeikou, the gateway to Beiping was invaded in March 10, 1933 and the battle lasted until May 14. In the first three days of battle, the number of Japanese casualties reached two thousand. During the whole period before the cease-fire agreement on May 31, 1933, at least 620,000 Chinese soldiers died in action. Twice as many died from disease. Infectious diseases such as dysentery, measles, smallpox, and pneumonia were the soldier's greatest enemies. The cold, poor hygiene, the lack of adequate sanitation, shelter and suitable clothing, the poor quality of food and water, and the crowded conditions were ideal breeding grounds for disease. ${ }^{8}$ Various estimates exist on the number of casualties inflicted during the Battle of Gubeikou, ${ }^{9}$ but one common estimate is as follows in chart 1 .

6. For a review of their work in medical modernization in China, $c f$. Bullock 1980; Ferguson 1970.

7. Lindsay 1945: 172-176; Hsu and Chang 1971: 159-161.

8. Zhonghua minguo waijiao wenti yanjiuhui 1965; Zhongguo Guomindang zhongyang weiyuanhui 1981; Liaoning renmin chubanshe 1991

9. Shi 2005: 517-573. 


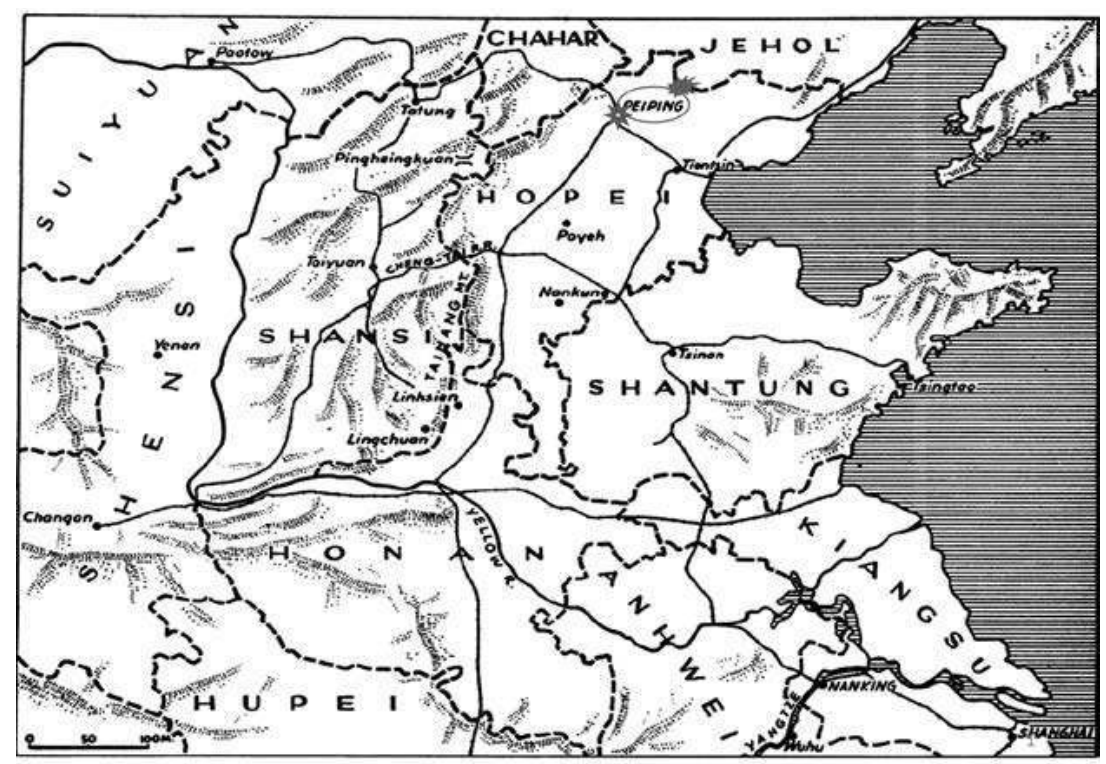

Source: Michael Lindsay (1945): 173.

Map 1. "The North China Incident"

\begin{tabular}{|l|l|l|l|l|}
\hline & \multicolumn{4}{|l|}{ Casualties } \\
\cline { 2 - 5 } & Killed & Wounded & Missing & Total \\
\hline Chinese & $6,100+$ & 24,000 & $8,000+$ & $38,100+($ est.) \\
\hline Japanese & $2,600-$ & 10,800 & $6,500-$ & $19,900+$ \\
\hline
\end{tabular}

Source: US, Department of State (1943). Peace and War: United States Foreign Policy, 1931-1941. Washington (D.C.), US, Government Printing Office: 44-52; Michael Lindsay (1945).

Chart 1. Casualty estimates for the Battle of Gubeikou between March 10 and 14

During the invasion of the North China Plain by Japanese troops, the Chinese government was unable to provide sufficient medical care and PUMC doctors played an important role in caring for both military personnel and the civilians caught up in the conflict. ${ }^{10}$ Dr. Robert Lim, a physiologist, at the

10. “Dr. Robert Lim Outlines Medical Relief Work,” no. 66, June 21, 1941, Daily Bulletin, China Information Committee, folder "National Red Cross Society of China, 
PUMC faculty organized the first medical supplies to the field at Gubeikou and secured relief from the International Red Cross. Robert Lim (1897-1969), was born in Singapore and studied medicine at Edinburgh University. He went on to head the PUMC Physiology department from 1926 to $1937 .{ }^{11}$ With his experience on the frontline in North China and his patriotic spirit, Dr. Lim became chairman of the Army Medical Administration in the Nationalist government's Military Affairs Commission in December 1937, just before the Japanese invasion of Nanjing.

Assistance provided by American funding had been, in part, to run medical schools such as those created in Beijing (1906), Jinan (1909), Chengdu and Changsha (1914), which were fully supported by American on-going donations from the Rockefeller Foundation. ${ }^{12}$ However, assistance provided by American funding was not only for the day-to day running of the medical schools; it also took the form of assistance in times of acute crises, such as when the Yellow River was flooded in 1938. Following the outbreak of the war in 1937, the Japanese army marched rapidly into the heart of Chinese territory. On June 6, 1938, they captured Kaifeng, the capital of Henan, and threatened to take over Zhengzhou, at the junction of the arterial Pinghan and Longhai Railways, which would have directly endangered the major cities of Wuhan and Xian. To stop further Japanese advances, Nationalist troops intentionally broke the levees of the Yellow River near Huayuankou to "use water as a substitute for soldiers." ${ }^{13}$ Water flooded into Henan, Anhui, and Jiangsu. The floods covered and destroyed thousands of square kilometers of farmland and shifted the mouth of the Yellow River hundreds of miles to the south. ${ }^{14}$ Thousands of villages were inundated or destroyed and several million villagers were driven from their homes. In the following months, cases of infectious diseases were reported in the flooded areas. Japanese records show that cholera, paratyphoid, dysentery, and severe diarrhea were often reported to local authorities. ${ }^{15}$ Each side tried to blame the other for the outbreaks. And while the Chinese government did not undertake a major relief operation to aid the displaced, the Japanese took every chance to promote their "merciful action" in saving

Robert K.S. Lim,” box 22, series II: Permanent file, ABMAC, RBML, Columbia University.

11. Rockefeller Archive Center (abb. RAC), RF archive, RG 2-1954, Series 601, Box 45, Folder 305, "Robert K.S. Lim."

12. On the medical schools in the first decades of the 20th century, $c f$. Lucas 1982; Anonymous 1933; and Yin 2008.

13. Lary 2004: 143 .

14. Lary 2001: 191-207.

15. Xin min hui nianbao 1938: 322-327. 
the population from the floods. ${ }^{16}$ However, there is no real evidence that either side engaged in much by way of emergency rescue activity in the immediate aftermath of the flooding unleashed on June 5. Any such operations would have had a very limited impact due to the huge areas affected.

The deliberate flooding of the Yellow River has been described as the "largest act of environmental warfare in history" ${ }^{17}$ causing the death of 470,000 to 500,000 people and the displacement of 5 to 6.1 million others. ${ }^{18}$ While the survivors blamed both the disaster on both the Japanese Imperialists and Chinese Nationalists, parts of the flooded region became a fertile recruiting ground for Chinese communists. ${ }^{19}$

The Nationalist government, although accused of inaction, ${ }^{20}$ did try to reduce the impact of the Huayuankou flooding, not through immediate action but through an urgent call for international assistance in this context of war. As early as 1933, in the defense of Gubeikou, Robert Lim had demonstrated the urgent need for military medicine in modern warfare in China, and also revealed the importance of the Red Cross Society of the Republic of China, the International Red Cross' Chinese branch, for first aid in the field, as well as a channel for receiving international aid. By 1937, despite friction between the different organizations - the PUMC, the Nationalist government, and the International Committee of the Red Cross - the implementation of an emergency healthcare system and the constitution of a medical corps became the top priorities of both Red Cross Society of the Republic of China and the National Health Department in Nanjing. ${ }^{21}$ The American Bureau of Medical Aid for China (ABMAC) was essential to Robert Lim's work. Set up mainly by Chinese Americans in 1937, ABMAC supplies were initially distributed to the Red Cross Society of the Republic of China and its Medical Relief Commission (later Corps), both headed by Robert Lim. At that time, China's armed forces had only the most rudimentary military medical services ${ }^{22}$ and civilian medical services were insufficient too. In early July, immediately after the flooding of Huayuankou, ABMAC was able to make a grant of $\$ 1,000$ to the Hankow Rest House and $\$ 1,000$ to the University Hospital in Nanjing from

16. Zhina shibian huabao, no. 33 (Meiri xinwen, July 11, 1938).

17. Taylor 2009: 154-155.

18. Perry 1980: 15 .

19. Lary 2001: 204.

20. Lary 2001: 204.

21. Zhang 2001.

22. Watt 1992: 2 . 
the Bureau's fund-raising efforts for Chinese refugees and flood victims. ${ }^{23}$ However, as Dr. Co Tui, ABMAC director, later stated "We had to hold on to the Nanking (Nanjing) funds, as the city fell into the hands of a puppet Japanese government at just about that time." ${ }^{24}$ It seemed that foreign medical aid was suspended.

\section{Reserving modern medical resources in wartime China}

As the war progressed, Japanese forces progressively took control of Shanghai, the capital Nanjing and Wuhan, forcing the Chinese central government to relocate to Chongqing, in Sichuan, southwest China which was far from the reach of Western medicine. Records from the time show 8,900 registered physicians, 2,740 pharmacies and dispensaries, 3,700 midwives and 575 nurses in the entire country ${ }^{25}$ In southwestern remote areas, most medical services were still provided by mostly unqualified practitioners and druggists practicing traditional Chinese medicine. In the countryside, where the majority of the population lived, practitioners were generally farmers who sold medicinal herbs as a sideline. ${ }^{26}$ The Nationalist government's retreat to Chongqing coincidentally brought the resources of modern medicine to this part of China, paving the way for post-war reconstruction.

The core of the limited medical resource in southwest China was the welltrained medical practitioners and public health workers who had retreated with the government. These professions had been greatly supported by the Nationalist government's medical modernization scheme in the 1930s. Dr. Robert Lim's colleague, Liu Rui-heng (Dr. J. Heng Liu), the former chancellor of the PUMC and a Harvard medical school alumni had played a key role in promoting this modernization project by adopting American standards. ${ }^{27}$ One of Liu's main tasks was to replace the dominant German configuration of Chinese military

23. RAC, RF archive, RG 2-1954, Series 200, Box 10, Folder 70 "Medicine on a Mission": 4,5 .

24. RAC, RF archive, RG 2-1954, Series 200, Box 10, Folder 70 "Medicine on a Mission": 4, 11.

25. Watt 1992: 3 .

26. The condition of medical services was commonly criticized by American donors. The Rockefeller Foundation and the CMB repeatedly played on the poor medical infrastructure in order to promote themselves as the heroic saviors of China. RAC, RF archive, RG 2-1954, Series 200, Box 10, Folder 70 "Medicine on a Mission": 1618.

27. For Liu Rui-heng's career, please refer to Liu 1989. 
medicine to meet the criteria of American standards. ${ }^{28}$ Liu's mission to reform medical training in the military was later taken over by Robert Lim and resulted in the creation of a reservoir of modern medical resources within the military as well as the maintenance of links with American supporters. ${ }^{29}$ This became very important when the Nationalist government retreated to Chongqing and relied heavily on military personnel to keep modern epidemic control systems running. Based on the experience he had gained in Northern China and through international connections with ABMAC as well as other American aid organizations, in 1938, Dr. Robert Lim set up the Emergency Medical Service Training School in Guizhou. This was the first such establishment for training doctors, nurses and medical orderlies for the army and civil relief services. This school later expanded to several campuses and units until 1942. The school's mission was to respond to the medical demands of the battlefield and to provide the means for post-war reconstruction. ${ }^{30}$ During the war, over 13,000 medical personnel of various categories were trained there. ${ }^{31}$ The Emergency Medical Service Training School was sponsored by the Nationalist government and ABMAC and staffed by some of Robert Lim's former PUMC students and colleagues. They worked alongside the renamed Medical Relief Corps in spreading modern medical knowledge to army medical personnel and local communities. During the whole period of resistance to the Japanese invasion, the Emergency Medical Service Training School worked with ABMAC and played a key role in receiving American aid and merging the German system into American standards. With the help of American resources received via ABMAC during this war period, Robert Lim continued the work in Guizhou that had been started in Nanjing by his former PUMC colleague Liu Rui-heng.

At first sight, the Emergency Medical Service Training School was set up for military purpose; however, the reasons behind its establishment in southwest China were more ambitious. A review document from the Rockefeller Foundation revealed that on the recommendation of ABMAC, the main target was to relocate the Army Medical Service Training Unit to the Emergency Medical Service Training School in Sichuan under Lim's commend. A CMB report from the time states: "I am certain that if there is continuity after the war in national health training, it will prove to be of a much more significant nature than pre-war training, due to the methods of

28. Wu 1995: 12-14.

29. Wu 1995: 13-29.

30. Liu 1993: 147.

31. RAC, RF archive, RG 2-1954, Series 601, Box 45, Folder 305, "Robert K.S. Lim.” 
training introduced in Changsha by Robert Lim." ${ }^{32}$ With the effects of the war, the project of establishing public health centers in the 1930s by Liu Ruiheng and its mission of controlling epidemics was so extended that the single Central Training Station in Chongqing was obviously insufficient. Boosted by graduates from the Emergency Medical Service Training School and army medical corpsmen, provincial and county centers were rapidly established, beginning with Guizhou and remote counties of Sichuan. ${ }^{33}$ For example, in 1941 the National Health Administration reported that 76 of 84 counties in Guizhou had established such health centers while only 11 counties had such services before 1935. ${ }^{34}$ In 1944, the Provincial government of Sichuan reported that 116 of 140 counties in Sichuan had "some form of health center." 35

The effort to continue the medical training program and local health reforms in southwest China was not intended to immediately reduce the health crisis in China during the war, but to maintain the capability to implement postwar reconstruction. From 1941, students from Emergency Medical Service Training School, for example, were asked to join the Army Sanitary Corps and the Red Cross Medical Relief Corps on the battle front and in unoccupied areas. While the school and its branches were designed to act as medical centers or battlefield stations in times of war, they would easily be converted to civilian healthcare in peacetime. ${ }^{36}$ By the end of 1943 , near $66 \%$ of the graduates of Emergency Medical Service Training School were removed from combat zones and relocated to various positions in civilian services. ${ }^{37}$ The Emergency Medical Service Training School and the Central School of Army Surgery were both located in Guizhou and provided medical care for the military and civilian population. ${ }^{38}$ Between 1941 and 1945, the Emergency Medical Service Training School therefore had a double role. It trained servicemen for medical duties and at the same time trained local people to respond to both military and civilian medical needs. ${ }^{39}$ Dr. Robert Lim planned that these local trainees would form the foundation for healthcare after the end of the war.

32. RAC, RF archive, RG 1.1, Series 601, Box 5-6, "Annual report, 1938."

33. League of Nations Health Organization 1938: 1-3. See also Bullock 1980: 193.

34. "Public Health and Medicine," China Handbook, 1937-1943 (New York, Macmillian, 1943): 667, 674.

35. Bullock 1980: 198-99.

36. Emergency Medical Service Training School (ed.), Announcement (1941): 1.

37. Emergency Medical Service Training School (ed.), Second Report (1942-1943): 4.

38. Emergency Medical Service Training School (ed.), Training Program: Stage medical Education (1941): 6-8.

39. Emergency Medical Service Training School (ed.), Training Program: Stage medical Education (1942): 12. 
The results of Dr. Lim's plan seemed positive. Major Mendelson of the US Army visited the Emergency Medical Service Training School in 1942, and declared that the technical short-term emergency training was managed effectively, showing good results in the prevention and mass-treatment of disease.$^{40}$ The progress of sanitary training was made in two ways: the enrolment of local helpers for public health services, and establishment of several nursing schools for young women. To improve the transportation of medical services, a field ambulance battalion was organized and staffed with Army medical officers and Red Cross personnel to teach local helpers how to coordinate supplies and personnel requirements. The purpose was to increase the numbers of trained medical personnel who could support the military in times of war and work in their local communities during peacetime. ${ }^{41}$ The picture showing the group photo of graduating stretcher-bearers attests to this effort (photo 1). Moreover, American officers were to be attached to these units, if available. Some of the best of Chinese officers and staff were sent to America for advanced training with the US Army. After returning home, they were charged with training as many instructors as possible, military and civilian, who would be sent to the front and to unoccupied areas. ${ }^{42}$ This strategy was clearly not only for the specific medical demands of wartime, but was also for the peacetime that would eventually follow.

In the 19th century, when the Chinese encountered Western medicine, their first sight was commonly a nurse caring for a patient. Although nurse training has a long history in China, dating from the arrival of missionaries and missionary medicine, according to the CMB only a few schools offered advanced nursing programs which could meet American standards. From 1920 onwards the PUMC served as the first graduate school for the training of teachers of nursing and hospital administrators and offered a combined course in which graduates of a two-year pre-nursing course could continue to a threeyear course at the PUMC leading to a Diploma in nursing and a Bachelor degree..$^{43}$ In 1930, the headquarters of the Nurses Association of the Republic of China (NARC), supported by the CMB, moved to Nanjing. In addition to Western nurses, the majority of NARC members were PUMC alumni, which reveals its close connection to American medicine. ${ }^{44}$

40. RAC, CMB Inc. archive, Series CMB, Box 122, Folder 886, "G. Correspondence."

41. Emergency Medical Service Training School (ed.), Second Report (1942-1943): 1617.

42. Emergency Medical Service Training School (ed.), Second Report (1942-1943): 17

43. Liu 1991: 315-324.

44. Liu 1991: 322-323. 


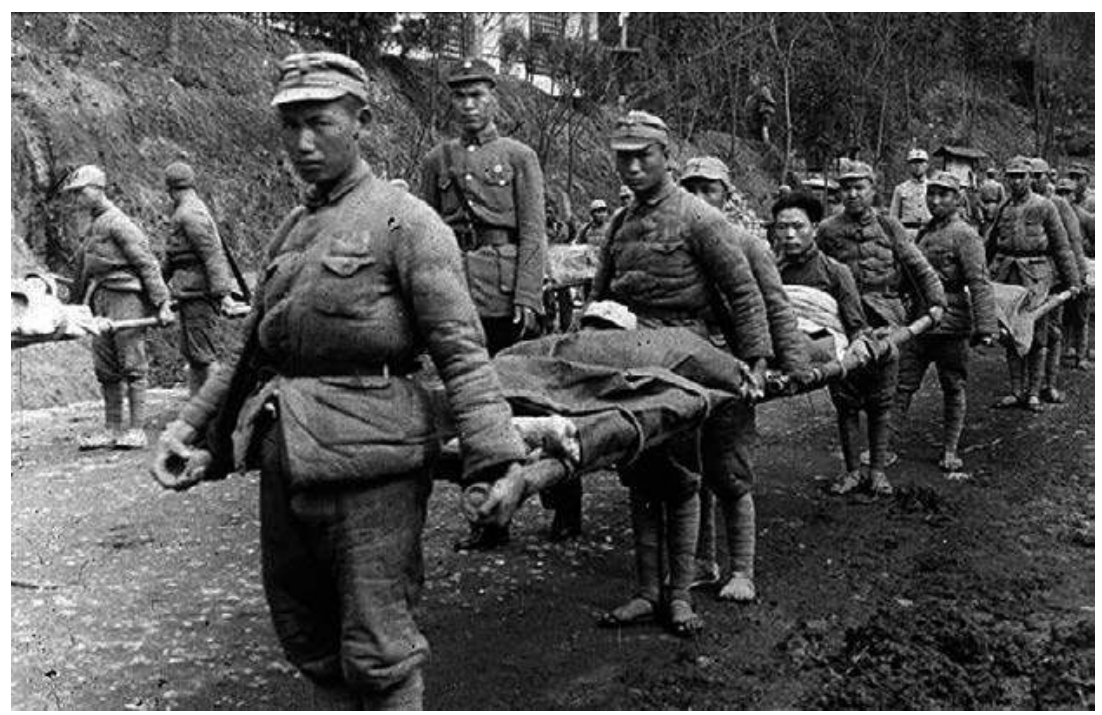

Courtesy by John Watt of ABMAC.

Photo 1. Bearer training and local stretcher-bearer.

During the Sino-Japanese war, many young Chinese women who aspired to serve their country were attracted by the nurse training programs. ${ }^{45}$ However, the Central School of Army Surgery was an all-male unit even in wartime. With continuing help and donations from the ABMAC, the Emergency Medical Service Training School at Tuyunguan had gained experience of treating open wounds with sulfanilamide powder. ${ }^{46}$ However, due to the limited number of military surgeons and civilian physicians in the region, most of the treatment was done by nurses or nursing orderlies trained at the Emergency Medical Service Training School. The nursing department of that school was headed by a PUMC graduate, Miss Zhou Mei-yu. Zhou divided the department into two training sections. One was a regular school for registered military and civilian nurses. The other was an intensive program in basic nursing skills, mostly addressed to local women who would later serve as formal nurses'subordinates. ${ }^{47}$ This form

45. Pan 1997: 129.

46. Emergency Medical Service Training School (ed.), Second Report (1942-1943): 51.

47. Emergency Medical Service Training School (ed.), Report (1943): 22. 
of nurse training was very beneficial to local communities and had a similar impact to the training of local stretcher-bearers. ${ }^{48}$

The selection of local candidates for Emergency Medical Service Training School nursing programs reveals China's socio-economic conditions. Graduation from a junior middle school was required for admission, while formal schools of medicine and nursing demanded senior high school graduation. The reason of such criteria was, as a recruitment poster reveals: "graduates (of junior middle school) those who already have sufficient cultural and political background will benefit their hometown at the same time as promoting national policy... At this age they are usually more receptive, idealistic, and unafraid of the difficulties and hardships in training and the mission of bringing new knowledge back to home... The graduates'families in their hometown are usually better off financially, which will also secure their social status at the same time as promoting modern medicine in conservative rural areas...." ${ }^{49}$ Although American observers in 1943 had criticized the Emergency Medical Service Training School's curriculum as "a limit to which unqualified personnel can be technicalized and promoted..." ${ }^{50}$, the effort to maintain modern healthcare systems in wartime China for post-war reconstruction was later carried on by the creation of the National Defense Medical Center in 1947. The NDMC moved with the Nationalist government to Taiwan in 1949, bringing with it some of its war-time experience.

\section{Post-World War II legacy one: fighting epidemics as if fighting the enemy}

In the optimistic atmosphere created by the victory against Japan in 1945, the Nationalist government announced a series of public health projects on its return to Nanjing. ${ }^{51}$ Although some of these projects were unrealistic in the devastated post-war conditions, several institutes were established with American support. ${ }^{52}$ For example, The Malaria Research Institute, founded in 1936 with support from the Rockefeller Foundation and the CMB, moved

48. The stretcher-bearer was mainly civilian but could be recruited to work as supplement combat medics. (Ibid.)

49. Emergency Medical Service Training School (ed.), Report-supplement (1942): 40-41.

50. RAC, CMB Inc. archive, RG 1-1945, Series CMB, Box 162, Folder 812, "G. Correspondence."

51. Chen 1981: 21.

52. Chen 1982: 14. 
from Yunnan to Nanjing with the Rockefeller Foundation's support in 1947. An experimental DDT spraying project was also set up in the same year with many tons of free chemicals from the US army. In 1947, Jiangning, a village outside the city of Nanjing, was jointly selected by the Rockefeller Foundation and the government to set up an experimental DDT spraying station-the first such demonstration station on Chinese territory-under the direction of malariologist Zhou Qinxian and American scientist Robert Briggs Watson. At this time, levels of malaria on the newly-liberated island of Taiwan were much lower than on mainland China and the island did not receive supplies of DDT. ${ }^{53}$ Despite medicine and sanitation being modernized during the Japanese colonial period (1895-1945), ${ }^{54}$ in early post-World War II years Taiwan was in bad shape and suffered from many epidemics. ${ }^{55}$ However, mainland China received the majority of American donations of medical resources until late 1947, when the provincial government in Taipei started to receive significant aid from the US. ${ }^{56}$

Controlling epidemics was not the only motive for the Nationalist government to resume the 1930s project and build on its wartime experience. During the first-half of the 1950s, the Nationalist government in Taiwan was eager to gain the support of the US to block invasion from mainland China. Maintaining philanthropic work such as epidemic control and public health improvement in Taiwan could be a strategy to continue the cooperation between Nationalist Taiwan and the US in the post-World War II era. ${ }^{57}$ After the end of the war, James A. Crabtree, Deputy Surgeon General of the US Public Health Service from 1946 to 1948 promoted the idea of building a new organization for international public health, ${ }^{58}$ a mission that had been carried out by the League of Nations before the war. World War II had severely curtailed the international cooperation-based disease control efforts carried out by the Health Section of the League of Nations in Geneva, a European city trapped in the debris of war damage. A proposal by Brazil and China to establish an international health organization in the 1945 San Francisco Conference was

53. RAC, Robert Briggs Watson, "Annual Report of Activities, 1946," RG 5, IHB/D, Series 3, Box 217, Folder 600. RAC, J.H. Paul, "A report on the year's activities for year 1946,” RG 5, IHB/D, Series 3, Box 217, Folder 600.

54. Liu 2009.

55. Chen 2000: 35-36; Zhuang 1998: 364-365.

56. RAC, “Annual Report 1949,” p. 3, RG 5, IHB/D, Series 3, Box 217, Folder 600.

57. Ambivalence about how the security situation in East Asia was assessed by the US can be found among seasoned experts. For example, Scalapino 1991/1992: 26, 32, 36.

58. Williams 1951: 487. 
soon recognized by the US Public Health Service. ${ }^{59}$ Civilian organizations including Johns Hopkins University, the Rockefeller Foundation, and the American Medicine Association recommended specifically that the United Stated government include non-governmental charity resources in the early formation of a new international organization that would be closely linked to the United Nations. ${ }^{60}$ With abundant American resources from both governmental and private organizations, the World Health Organization represented a multilateral approach to international public health, also mobilizing the cooperation of many nations in pursuing common goals. ${ }^{61}$ The involvement of American civilian doctors and military surgeons for public health reconstruction in East Asia was benevolent but also political and strategic. Public health and medical reform in China could be seen as part of the broader American model of the professionalization of medicine in an East Asian ally after World War II.

When the first WHA (World Health Assembly) conference passed the charter to establish the WHO in 1948, the Nationalist government in China had already lost diplomatic support from the US government along with all forms of aid. After the failure of negotiations by General George C. Marshall in China, President Truman announced in The China White Paper in August 1949 the withdrawal of all support from China and blamed the decision on corruption in the Nationalist government. The damage to the Nationalist government was tremendous; it notably caused its retreat to Taiwan. ${ }^{62}$ Following this change of US diplomatic policy toward China, the China Medical Board also stopped its aid to China and prepared to withdraw its staff from Taiwan. ${ }^{63}$ Even Robert Lim was losing his support from American colleagues in US, as one member of CMB put it: "nor am I sure that he is still serving in that capacity (of seeking donations in/from the US)." ${ }^{64}$ Moving to Taiwan and making compromises to

59. Williams 1947: 68 .

60. World Health Organization (ed.) 1958: 38-40.

61. Williams 1951: 821-824.

62. Zhuang 2000: 143-144. Although the letter from the Rockefeller Foundation to the CMB did not point out the causality between the China White Paper and the withdrawal of personnel, it did quote from the China White Paper to illustrate the Sino-American relations. For cases, please check RAC, "Letter from Chester I. Barnard to John D. Rockefeller 12, Sept., 1950," Collection: RF, RG: 2-1950, Series 200: US, Box 478, Folder 3207.

63. RAC, "Letter from Dr. Balfour to Dr. Strode, 25, Feb., 1949," Collection: RF, RG: 1, Series 601, Box 44, Folder 361.

64. RAC, "Letter to Dr. Hugh Smith, May, 22, 1950," Collection: RF, RG: 2-1950, Series 601, 605, Box 501, Folder 3349-3350. 
accept doctors who had been trained in Japanese colonial medicine was the only solution for the Nationalist government in 1949.

At the end of World War II, Taiwan was returned to China and became reintegrated into China's administrative structure. As far as health matters were concerned, the island not only underwent changes in the organization of its health agencies, but was also very affected by the spread of diseases from the mainland ${ }^{65}$ In 1945 , the Taiwanese provincial government reorganized the health model inherited from the Japanese by removing Public Health from the Police Department and placing it in a new Bureau of Sanitation (Weishengju) ${ }^{66}$ The change did not, however, create a strong and efficient agency. A scholar underlined how public health in early postwar Taiwan was merely a system that "put out fires," and not a reliable system to handle the needs of public health. ${ }^{67}$ In 1946, a Rockefeller Foundation evaluation of sanitary conditions in Taiwan revealed the "modern" and "medieval" aspects of Japanese colonial sanitation. The use of night soil for fertilizer, sleeping and living on wooden floors in small damp houses, and many other customs were potential public health risks. Before World War II, the Sanitary Police were in charge of environmental sanitation but its members lacked proper training in public health and its budget was limited. ${ }^{68}$ Undoubtedly, post-war Taiwan urgently needed new health resources and administrative skills to fill the vacuum caused by the defeat of the Japanese in August 1945. Changes of government, economic depression, movements of people, shortages of medication, and the neglect of the public health infrastructure all contributed to the resurgence of infectious diseases in Taiwan between 1946 and 1947. Cases of cholera, smallpox, and plague were reported, and it is estimated that more than one million people were infected with malaria during these years.

In order to stop the further spread of epidemics from mainland China, new regulations for port quarantine, based on the most updated standards, became effective in December 1946. Taiwanese personnel manned the ports of entry under the guidance of Chinese officials, who were themselves trained in laboratory techniques under American supervision. ${ }^{69}$ Owing to the poor health

65. For a case study of epidemics in early post-World War II Taiwan, see Chen 2000.

66. Su 2004: 185 .

67. Chen 2000: 101-105.

68. RAC, CMB, RG 5, IHB/D, Series 3, Box 217, Folder 600, “Annual Report 1949”: 3-5.

69. "Gechu guanyu meiyun yiyao buzhu defang de yuebaobiao he laiwang gongwen" [Various monthly reports and documents on American medical aid], archives of Weishengbu (National Health Department), Box 372, no. 613 (1947), The Second Historical Archives of China (Nanjing). 
conditions in post-war Taiwan, the Chinese Nationalist government put in place stringent immunization requirements, and in 1947, revised the regulations to bring them more in line with standard international quarantine practices. ${ }^{70}$ Under the supervision of the Plague Prevention Division of Southeast China, a section of the National Health Department of the Nationalist government that channeled foreign medical aid, quarantine controls proved successful.

The diversion of labor and materials during the Sino-Japanese War had a dramatic impact on epidemic control, even by the relatively low 1945 standards. Smallpox vaccination programs were either completely discontinued or were not enforced from 1945 to 1946 . Environmental sanitation was virtually nonexistent, while public water supply and waste collection facilities had been severely damaged in areas that had been bombed or suffered from lack of funds. ${ }^{71}$ Those areas that escaped the devastation of war had deteriorated badly through neglect, as well as a shortage of materials and supplies. The withdrawal of American organizations further suffocated the re-construction of the public health infrastructure in Taiwan. The ABMAC along with other American organizations had cooperated with the Nationalist government to improve public health in China during and after the Sino-Japanese war. ${ }^{72}$ But unlike the $\mathrm{CMB}$ and other American counterparts, the ABMAC continued to cooperate with the Nationalist government after its retreat to Taiwan. ${ }^{73}$ Aware of the decision made by the US State Department and CMB, the ABMAC chose to support the Nationalist government in Taiwan. ${ }^{74}$

ABMAC saw communism as a threat to religious freedom, and especially to Christianity. To keep the donation to "Free China (Taiwan)," the Executive Committee of ABMAC repeatedly asserted "No gift to the ABMAC ever goes to Communist-held areas [...] the donation will only be sent to Free China." 75 Between 1949 and the outbreak of the Korean War in 1952, the ABMAC was the sole channel of American influence in public health in Taiwan. Working with the National Defense Medical Center in Taiwan, Liu Rui-heng replaced

70. RAC, CMB, RG 5, IHB/D, Series 3, Box 217, Folder 600, “Annual Report 1947.”

71. RAC, CMB, RG 5, IHB/D, Series 3, Box 217, Folder 600, “Annual Report 1949.”

72. Watt 1992.

73. RAC, RF, RG: 2-1949, Series 200US, Box 441, Folder 2969, "Medicine on a Mission: A History of American Bureau for Medical Aid to China, Inc. 1937-1954": 28 (section III).

74. RAC, RF, RG: 2-1949, Series 200US, Box 441, Folder 2969, “ABMAC, Board Director's Meeting Agenda."

75. RAC, RF, RG: 2-1951, Series 200, Box 516, Folder 3449, "Note of ABMAC, 21, May, 1951." 
Robert Lim as ABMAC representative. ${ }^{76}$ To secure the limited medical aid from the ABMAC, Liu encouraged the NDMC faculty to resume some programs that America had proposed earlier in pre-civil war mainland China. Starting in 1951, the former malariologist at the Nanjing station Zhou Qinxian and Zhang Teling, an NDMC parasitologist initiated a DDT spraying pioneer project in South Taiwan. ${ }^{77}$ The project was in fact the miniature version of that carried out in 1947 on the mainland with ABMAC support. The pioneer project was later expanded to an island-wide program in $1952^{78}$ which was soon recognized by the WHO as a part of the global anti-malaria program.

American medical aid to China and Taiwan helped break down the fatalistic view of diseases and natural disasters as parts of the regular natural cycle: by blaming plagues and the flooding on the Japanese invasion, they drew a link between fighting to victory on the battlefield and fighting the ravages of epidemics and natural disasters. A cartoon in 1947 of the first annual report of the NDMC dramatically reflected such a link (Photo 2). Treating diseases and public health crises as a real enemy in a combat situation had strong resonance in post-war Taiwan and left a deep impact on the anti-malaria program in the 1950s and 60s. ${ }^{79}$

The outbreak of the Korean War in 1952, with the USSR and Communist China supporting North Korea and the USA supporting the South, intensified the Cold War and brought American medical aid back to Taiwan. American sources of medical aid in the 1950s and 1960s included public agencies such as the Economic Cooperation Administration, private foundations such as the Rockefeller Foundation, the Population Council, and the ABMAC as well as the General Headquarters (GHQ) in Tokyo, and universities such as Princeton and the University of Michigan. Foreign assistance brought new forms of medical treatment and also introduced very different strategies in the identification of disease and public health problems. ${ }^{80}$

76. Zhang 2000: 616-622.

77. Wu 1995: 37 and 41.

78. Xingzhengyuan weishengshu 2003: 23-25.

79. Lin and Liu 2010: 183-208.

80. Yang 2008: 91-139. 


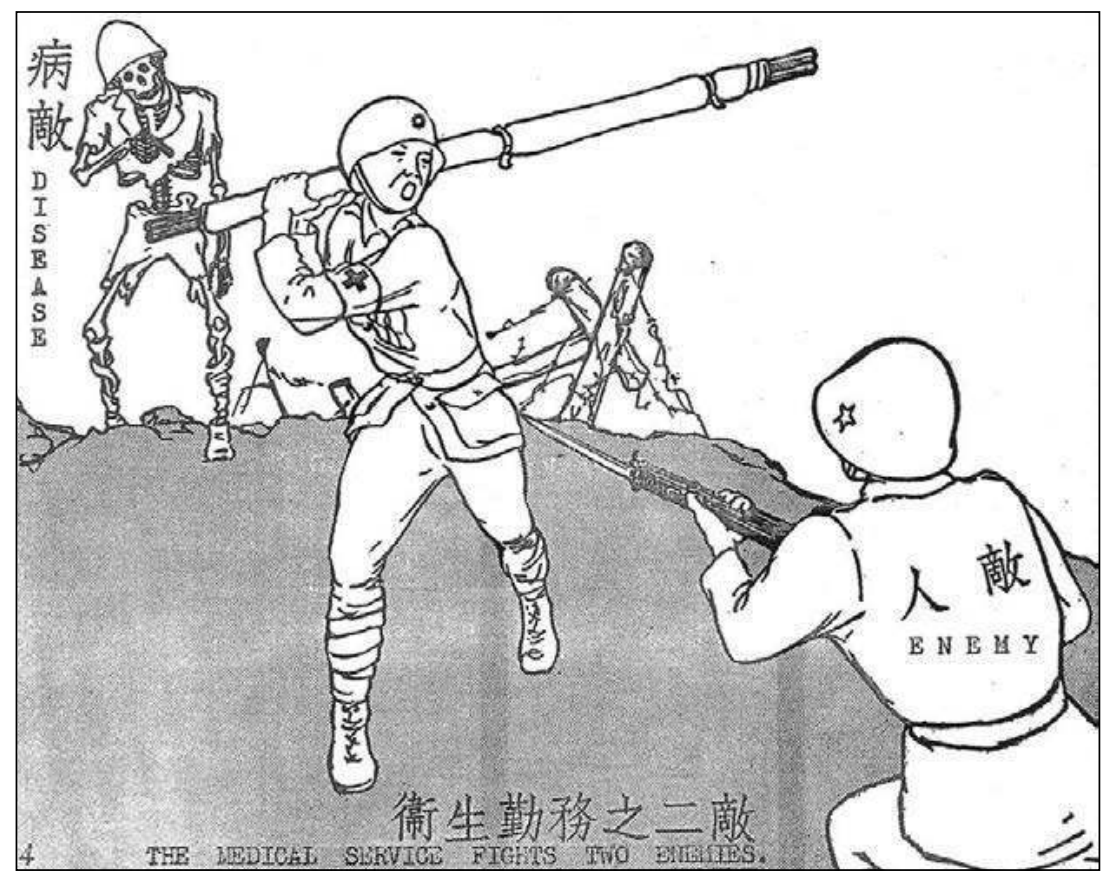

Source: The Second Annual Report of NDMC (1948).

Photo 2. The double-mission to fight enemy and disease.

\section{Post-World War II legacy two: the American panacea and Taiwanese takers}

The malaria eradication campaign is a very good illustration of the importance of the American model of public health and medicine in health development in postwar Taiwan. The campaign was also part of a global effort to combat this deadly disease by DDT indoor residual spraying (IRS). While Randall Packard ${ }^{81}$ and Yip Ka-che ${ }^{82}$ have demonstrated that the result of the campaign depended to a significant extent on the social and political conditions of each country, and on the importance to have qualified personnel, in East Asia, Taiwan was a successful case in this global DDT campaign of malaria eradication.

81. Packard 2007.

82. Yip 2009. 
The DDT program launched in 1951 directly linked anti-malarial activities in Taiwan to a global effort in partnership with the WHO. The first objective of the 1951 agreement between the Nationalist government in Taiwan and the WHO was "the control of malaria and eventually the eradication of this disease in the whole island of Taiwan, with modern methods at the lowest feasible cost." ${ }^{83}$ The project aimed to control malaria and other insect-borne diseases, and improve the health of the population, agricultural production as well as the general economy. The eradication program was preceded for two years by scientific study into the effectiveness of IRS DDT spraying when applied to walls made of different materials, field research into mosquito habitats, and cost-effectiveness studies of the various eradication procedures ${ }^{84}$ Generous financial and technical support from the US helped ensure the success of the program, which benefited almost every aspect of life in Taiwan.

The 1950s'DDT program in Taiwan not only laid the foundation for future malaria control by combining knowledge and experience from Taiwan's colonial past and mainland China, but also significantly boosted Taiwanese confidence in American public health practices. Along with the rising confidence in American medicine, more reforms were on the way. Two American experts, Van Hoge and Ross Porter, produced an evaluation of public hospitals in Taiwan in 1952 that recommended a radical make-over of the whole system. ${ }^{85}$ To further promote the American model of public health, the Nationalist government launched a five-year Integrated Health Project in 1959 to train Taiwanese medical professionals in the "integration of curative and preventive medical service" 86 - a radical change from colonial medical training to a much broader public health approach. In addition, American experts pointed to the general weakness of environmental sanitation in post-war Taiwan as a result of the Japanese colonial policy of focusing mainly on urban sanitation. Working with the Sino-American Joint Commission on Rural Reconstruction (JCRR), ${ }^{87}$

83. "Annexes to the Plan of Operations for Malaria Eradication in China (Taiwan)," Document 2025, 69, Taiwan Provincial Malaria Research Institute (TAMRI).

84. Watson and Liang 1950: 471-486; Watson, Paul and Liang 1950: 25-43.

85. "Counterpart Budget - PH CY-1953," March 30, 1953; "CY-53 Counterpart Allocation," June 9, 1953, CIECD36-11-003-001, Institute of Modern History of Academia Sinica (hereafter IMHAS).

86. “Application for Local Currency AID Funds-Project \#84-55-514,” Dec. 29, 1959, CIECD36-11-003-046, IMHAS.

87. The Sino-American Joint Commission on Rural Reconstruction (JCRR) was established in 1948 in mainland China, then moved to Taiwan, where its work has been widely credited with laying the agricultural basis in the 1950s and 1960s for Taiwan's economic, social, and technical development. For its brief history, see Yager 1988. 
American aid agencies subsidized the establishment of the Provincial Institute of Environmental Sanitation which went on to create many rural health stations in 1955. ${ }^{88}$ The "rural health station," an organization that had been launched in the 1910s by PUMC, was maintained during the 1940s in wartime China, and was then extended island-wide in Taiwan. In addition to setting up the rural health stations, the Institute also trained nurses and technicians who would work in them. The training unit was under American supervision. ${ }^{89}$ It is worth noting that many rural public health projects in Taiwan originated from the JCRR's original plans and experience in mainland China.

The retreat from the mainland brought to Taiwan transmissible diseases as well as new ideas and technologies to control them, such as the JCRR rural health station plan and the DDT spraying program and other ideas and technologies. With a long history of embracing American medical education and practices, medical professionals who had retreated from the mainland with the Nationalist government, especially military surgeons, attempted to reshape the Japanese medical model in Taiwan, stressing the nationalistic aspect of the change. Ironically, the pressure of postwar epidemics and coldwar politics brought a focus to the efforts to reshape public health practices in Taiwan which might otherwise have resulted merely in conflicts among various medical factions.

In 1949, with help from the CMB and the ABMAC, two-thirds of the NDMC staff moved to Taiwan. In Taiwan, General Zhou Mei-yu received American support for military nursing education at the NDMC. ${ }^{90}$ Yu Daozhen, a protégée of General Zhou, was invited to set up a Department of Nursing at the National Taiwan University (NTU) in $1956 .{ }^{91}$ Following the guidance of her mentor General Zhou and American supporters, Yu transformed the military nursing training program into a public health nursing program. ${ }^{92}$ The

88. "Taiwan shengzhengfu weishengchu zhi meiyunhui han" [Letter from Taiwanese Provincial Health Department to CUSA], April 5, 1957 and "Project Agreement Between ICA and CUSA," March 6, 1958, CIECD36-11-003-067, IMHAS.

89. "Project Proposal \& Approval Summary (\#84-52-291)," Jan. 8, 1957, CIECD36-11-003-067; "Report of Sanitarian Training Program," Nov. 1, 1957; "Taiwansheng huanjing weisheng shiyenso zhi J. I. Connolly han" [Letter from Taiwan Provincial Institute of Environmental Sanitation to J. I. Connolly], June 6, 1958, CIECD36-11-003-067, IMHAS.

90. Memorandum: "Improvement of Nursing Practice Project-FY 1957 Program," August 31,1960; "FY 59 PPA-Aid to Medical and Paramedical Education (Improvement of Nursing Practices)," August 18, 1958, CIECD6-11-003-038, IMHAS.

91. Cai 2001: 261-262.

92. Chen 1996: 80. 
ABMAC, the RF, and the CMB provided additional support to help establish nursing schools at various levels, and in implementing the rural health station project. ${ }^{93}$ In addition, Yu's students also claimed that "the reform of nursing education at the NTU led to the transformation from the German-Japanese system to the British-American system." ${ }^{4}$

From 1952, the authorities in Taiwan began formulating long-term plans for improvements based on previous Rockefeller Foundation proposals, but any implementation of the plans would depend, to a large extent, on the cooperation of local governments and medical professionals in Taiwan. Following the outbreak of the Korean War, the US Foreign Operations Administration (FOA) sent Emile E. Palmquist and Kaarlo W. Nasi to review Taiwan's medical and public health conditions. ${ }^{95}$ Their report later served as the basis for the US AID Health Program in Taiwan aimed at maintaining economic stability and military power in Taiwan. The report stressed that the target institute to which an ambitious program of rehabilitation and technical support would be affiliated should be carefully selected. ${ }^{96}$ Moreover, as Dr. Edger Hull, Medical Consultant to the Mutual Security Agency mission to China (MSA) expressed his strong concerns about the quality of the NDMC public health program, ${ }^{97}$ the dean of pathology at NTU also started the "Americanization" of its public health program at NTU with NDMC's close cooperation. ${ }^{98}$

In 1951, two American public health experts from the ABMAC, Dr. Magnus I. Gregersen and Dr. George H. Humphreys of Columbia University, evaluated the medical school at the NTU. Although their proposal for medical school reform was too expensive to be implemented, their visit brought the school to the Rockefeller Foundation's attention and ABMAC later provided some support to the school. ${ }^{99}$ In late 1951, the former dean of the Public Health Department of PUMC, Dr. John B. Grant, was invited by Liu Rui-heng to help the conversion of the Tropical Institute at NTU into a Department of Public Health which was later established with the Rockefeller Foundation's full support. The successful creation of nursing and public health departments

93. Yang 2008: 111.

94. Liu 2006: 17.

95. "Zhi naizhengbu Taiwan shengzhengfu hangao" [Draft: letter from CUSA to the Ministry of Internal Affairs and Taiwan Provincial Government], Sept. 16, 1954, CIECD36-11-003-001, IMHAS.

96. Yang 2008: 108 .

97. Lu Zhider zhi meiyuanhui han (Letter from Lu Zhider to CUSA), Aug. 7, 1958, CIECD36-11-003-104.

98. Yeh 1989: 56.

99. Watt 1995: 174-177. 
laid the foundation for long-term cooperation between the NTU and various American aid organizations. ${ }^{100}$ In 1955, the US Naval Medical Research Unit No. 2 (NAMRU-2) decided to relocate to the affiliated hospital of NTU in Taipei. Affiliation with an advanced research institute and a significant symbol of American medicine in the Far East, vastly enhanced the NTU's prestige in the eastern Pacific Rim region. ${ }^{101}$ With this decision, American medicine was overwhelmingly accepted by Taiwanese and the strategic relationship between the two countries could be further secured as the US AID Health Program had expected.

During the 1950s, although the proportion of direct public health and medical aid to Taiwan was relatively insignificant, accounting for about $6 \%$ of the total amount of American aid between 1951 and 1965, ${ }^{102}$ the major portion of US support for Taiwan's public health and medical improvements was more indirect, being found in other aid projects. For example, around $10 \%$ to $15 \%$ of the American aid was earmarked for work in rural reconstruction which would lead to public health benefits. Meanwhile, the Council for United States Aid (CUSA) and the Taiwanese Provincial Health Department worked together in coordinating foreign medical aid from the United Nation Children's Fund (UNICEF), the World Health Organization (WHO), and ABMAC. ${ }^{103}$ Soon after the successful conclusion of the DDT anti-malaria program, people in post-war Taiwan came to believe that foreign aid in medicine would definitely improve public health and medical conditions in the island.

\section{Concluding remarks}

This article shows that the role that American philanthropic organizations such as the Rockefeller Foundation, the China Medical Board, and the American Bureau for Medical Aid to China fulfilled in the public health modernization of the country was highly limited in the case of Republican China. If their work in Mainland China during the Sino-Japanese war was an anomaly, it nevertheless influenced philanthropic interventions in other parts of post-World War II East Asia, ${ }^{104}$ and particularly in Taiwan during the Cold War. On the surface, US

\footnotetext{
100. Medical School of NTU (ed.), middle volume 1998: 16; Du 2008: 27, 29.

101. Xie 1995: 178-181.

102. Zhao 1985: 27-51.

103. Yang 2008: 95-96.

104. Similar pattern of medical intervention on epidemic control to Taiwan can also been found in Southeast Asia. See Anononymous 1954.
} 
funded public health reform in China is in line with the global promotion of American epidemic control principles by these philanthropic foundations. The control of epidemics in Taiwan was a philanthropic mercy as well as a military strategy. ${ }^{105}$

How did epidemic control become a strategic tool in the Cold War? During his trip to Asia in 1953, political observer James Reston reported:

America's contribution to the safety and sanity of Asia, however, goes well beyond the products of her factories... In Korea, Japan and Formosa (Taiwan), dependence on America is so great as to be almost pathetic. I had long talks with Syngman Rhee, Premier Yoshida of Japan and Chiang Kai-shek. Each in his own way had criticisms to make of American policy and all were asking more. ${ }^{106}$

Reston's description may have merely revealed the general feeling about American medical aid to East Asia where Free China or Taiwan is located.

In these conditions, American medical models and professional practices eventually guided public health reform in Taiwan between 1952 and the 1960s, creating new methods for epidemic control and new professional standards for the postwar generation. In the 1960s, as the crude death rate of Taiwanese males dropped to less than one per cent,${ }^{107}$ the phenomenon implied a dramatic transformation of leading causes of death. The success of the epidemic control program must have played a significant part in such a transformation (Chart 2).

105. Siggers 1954.

106. Reston 1953.

107. National Health Administration, online databank on website: http://www.doh.gov.tw/ CHT2006/DM/DM2_2.aspx?now_fod_list_no=9510\&class_no $=440 \& l e v e l \_n o ~=1$ (2013/5/5 accessed) 


\begin{tabular}{|l|l|l|l|}
\hline 1942 & \multicolumn{2}{|l|}{1952} & \\
\hline Diseases & Percentage & Diseases & Percentage \\
\hline Malaria & 10.7 & Gastris and enteritis & 14.2 \\
\hline Maternal causes & 9.2 & Pneumonia & 13.8 \\
\hline Gastris and entritis & 8.5 & Tuberculosis & 9.6 \\
\hline Tuberculosis & 7.1 & Heart disease & 5.2 \\
\hline Stomach and peptic ulcer & 6.8 & Stroke & 5.1 \\
\hline Pneumonia & 4.4 & Perinatal mortality & 4.6 \\
\hline Bronchitis & 4.1 & Nephritis and nephritis & 3.8 \\
\hline Meningitis & 1.9 & Cancer & 3.2 \\
\hline Stroke & 1.4 & Bronchitis & 3.0 \\
\hline Heart disease & 1.3 & Malaria & 2.9 \\
\hline
\end{tabular}

\section{Chart 2. Leading causes of death in Taiwan in 1942 and 1952}

Sources: Taiwan Provincial Government (ed.) (1947). Taiwansheng wushiyi nien lai tongji tiyao (The 51-Year Statistical Summary of Taiwan Province). Nantou, Taiwan Provincial Government, digital data on http://twstudy.iis.sinica.edu.tw/twstatistic50/and National Health Administration, online databank on website: http://www.doh.gov.tw/CHT2006/DM/ DM2_2.aspx?now_fod_list_no=9510\&class_no $=440 \& l e v e l \_n o=1(2013 / 5 / 5$ accessed $)$.

The transition from Japanese colonial medicine to a system based on American standards brought medical professionalism in Taiwan to contemporary levels. Many scholars have therefore seen that the 1950s was a crucial period in the first stage of demographic transition in Taiwan which provided human resources to the fast economic growth experienced during the 1970s-1980s. ${ }^{108}$ Chart 2 again confirms this health transition. ${ }^{109}$ Generally speaking, Cold War politics played a key role in bringing American medicine to Taiwan as described above. However, without the earlier cooperation in mainland China, the Americanization of public health infrastructure in Taiwan after the retreat of Nationalist government in 1949 might not have been smooth and rapid as it was.

108. Such an argument is very popular in the fields of demographic studies and development economics. For a review of this argument and its impact to social transformation in Taiwan, $c f$. Freedman 1986.

109. A change in disease patterns in populations testifies to a health transition which is determined by four elements: Urbanization, demographic, epidemiologic, socioeconomic and health care. For detail definitions, see Olshansky and Ault 1986. 


\section{BIBLIOGRAPHY}

\section{Archives}

EMERGENCY MEDICAL SERVICE TRAINING SCHOOL (ed.) (1941). Announcement.

EMERGENCY MEDICAL SERVICE TRAINING SCHOOL (ed.) (1941). Training Program: Stage medical Education.

EMERGENCY MEDICAL SERVICE TRAINING SCHOOL (ed.). Second Report (1942-1943).

MAINICHI SHIBUN 每日新聞 (ed.) (1938). Zhina shibian huabao 支那事变画報 (The illustration of China Incidents) (Japanese).

National Health Department (1947). Archives of Weishengbu 衛生部. Nanjing, The Second Historical Archives of China.

XIN MIN HUI 新民會 (ed.) (1938). Xin min hui nianbao 新民會年報 (Annual report of Xin min hui) (Chinese).

\section{Monographs and articles}

Anonymous (1933). "Zhongguo de yixue jiaoyu (medical education in China)," Dakongbao (May, 6).

Anonymous (1954). “An Asian Aid Program,” New York Times Nov. 20.

Bu Liping and YIP Ka-che (eds.) (2011). Science, Public Health and the State in Modern Asia. London, New York, Routledge.

Bullock Mary (1980). An American Transplant: The Rockefeller Foundation and Peking Union Medical College. Berkeley, Los Angeles/London, University of California Press.

CAI Xinge 蔡幸娥 (2001). Huli de xinxin: zouguo Taiwan lishi de zuji 護理的信心 一一走過台灣歷史的足跡 (Confidence of nursing: walking on the footprint of Taiwanese history). Taipei, Huateng.

CHEN Ji-chan 陳寄禪 (1981). Zhui su wu shi nian lai cu jin wo wei sheng she shi zhi guan jian shi ji 追溯五十年來促進我衛生設施之關鍵事蹟 (Reviewing of key works of sanitary infrastructures in our country over the past 50 years). Taipei, Zhenzhong shuju.

CHEN Shu-fen 陳淑芬 (2000). Zhan hou zhi yi: Taiwan de gong gong wei sheng wen ti yu jian zhi (1945-1954) 戰後之疫：台灣的公共衛生問題與建制 1945-1954 (Post-war epidemics: the problems and establishment of Taiwan's public health). Taipei, Dao xiang chubanshe.

CHEN Yuezhi 陳月枝 (1996). Yu Daozhen jiaoso huiyilu 余道真教授回憶錄 (The memoirs of Professor Yu Daozhen). Taipei, Alumni of nursing department of NTU.

China Ministry of Information (1943). "Public Health and Medicine," China Handbook, 1937-1943. New York, Macmillan.

Du Congming (2008), "The development of medical education in Formosa." In Watt, John R. Health Care and National Development, 1950-2000. New York, The ABMAC Foundation. 
Ferguson Mary E. (1970). China Medical Board and Peking Union Medical College. A Chronicle of Fruitful Collaboration. 1914-1951. New York, China Medical Board.

FreEdMAn Ronald (1986). "Policy Options after the Demographic Transition: The Case of Taiwan." Population and Development Review, vol. 12, no. 1: 77-100.

Hsu Long-hsuen and Chang Ming-kai (1971). History of The Sino-Japanese War (1937-1945), trans. Wen Ha-hsiung. Taipei, Chung Wu Publishing: 159-161.

LARY Diana (2001). "Drowned Earth: The Strategic Breaching of the Yellow River Dyke, 1938," War in History, vol. 8, no. 2: 191-207.

LARY Diana (2004). “The Water Covered the Earth: China's War-induced Natural Disaster." In Mark Selden and Alvin Y. So (eds.), War and State Terrorism: The United States, Japan, and the Asia-Pacific in the Long Twentieth Century. Oxford (UK), Rowman \& Littlefield Publishers: 143-170.

League of Nations Health Organization (ed.) (1938). War and Epidemics in China Geneva, League of Nations Health Organization.

LIAONING RENMIN CHUBANSHE (ed.) 遼寧人民出版社編 (1991). Jiu yi ba shibian dangan shiliao jingbian 九一八事變檔案史料精編 (The selection of historical archives of 918 Incident). Shenyang 瀋陽, Liaoning renmin chubanshe 遼寧人民出版社.

LiN Yi-Ping and Liu Shiyung (2010). "Forgotten Wars: Anti-Malaria Campaign in Taiwan, 1905-1965". In Angela Ki Che Leung and Charlotte Furth (eds.), Health and Hygiene in Modern Chinese East Asia. Durham, Duke University Press: 183208.

Lindsay Michael (1945). "Conflict in North China: 1937-1943.” Far Eastern Survey, vol. 14, no. 13: 172-176.

Liu Chung-Tung 劉仲冬 (1991). "From san gu liu po to 'caring scholar': the Chinese nurse in perspective.” International Journal of Nursing Studies, vol. 28, no. 4: 315-324.

Liu Michael Shiyung (2011). "From Japanese Colonial Medicine to American-Standard Medicine in Taiwan-A Case Study of the Transition in the Medical Profession and Practices in East Asia." In Liping Bu and Ka-che YIP (eds.), Science, Public Health and the State in Modern Asia. London/New York, Routledge: 162-176.

Liu Michael Shiyung (2009). Prescribing Colonization: the Role of Medical Practice and Policy in Japan-Ruled Taiwan. Ann Arbor, (Michigan), AAS.

Liu Si-jin (ed.) (1989). Dr. J. Heng Liu and Medical and Health Development in China. Taipei, The Commercial Press.

Liu Zhongdong 劉仲冬 (2006). “Woguo de huli fazhangshi” 我國的護理發展史 (The development history of nursing in our country). Huli zazhi 護理雜誌 (Journal of nursing), vol. 53, no. 3: 6-20.

LuCAs AnElissa (1982). Chinese Medical Modernization. New York, Praeger Publishers: 69-70.

Medical ScHOOL of NTU (ed.) (1995). Taida yiyuan bainian huaijiu 臺大醫院百年懷 舊 (Remembering the NTU hospital in the past 100 years). Taipei, the Medical School of NTU. 
Olshansky S. Jay and Ault A. Brian (1986). "The 4th Stage of the Epidemiological Transition.” The Milbank Memorial Fund Quarterly, no. 64: 355-391.

PACKARD Randall M. (2007). The Making of a Tropical Disease-A Short History of Malaria. Baltimore (MD), The Johns Hopkins University Press.

PAN Yihong (1997). "Feminism and Nationalism in China's War of Resistance against Japan." International History Review, vol. XIX: 115-130.

PERry Elizabeth (1980). Rebels and Revolutionaries in North China. Stanford (CA), Stanford University Press.

Reston James (1953). “America in Asia: Time and a Little Hope.” New York Times, August 30.

SCAlapino Robert (Winter 1991-1992). "The United States and Asia: Future Prospects." Foreign Affairs, vol. 70, no. 5: 19-40.

SELDEN Mark and So Alvin Y. (eds.) (2003). War and State Terrorism: The United States, Japan, and the Asia-Pacific in the Long Twentieth Century. Oxford (UK), Rowman \& Littlefield Publishers.

SHI-DING 史丁 (2005). Riben Guandongjun qin Hua zui'e shi 日本關東軍侵華罪惡 史 (History of the Criminal Invasion of China by Japanese Guandong army). Beijing, Shehui kexue wenxian chubanshe.

Siggers Philip (1954). “Aids to Formosa,” Washington Post, October 6.

Su Yaochong 蘇瑤崇 (ed.) (2004). Zuihou de Taiwan zongdufu: 1944-1946 zhongzhan ziliaoji 最後的台灣總督府－1944-1946 終戰資料集 (The last Government of Taiwan General-Governor: the Post-war archive collection, 1944-1946). Taizhong, Chenxing.

TAYlor Jay (2009). The Generalissimo: Chiang Kai-Shek and the Struggle for Modern China. Cambridge (MA), Harvard University Press.

WATsOn R. B. and LiAng K. C. (1950). "Seasonal prevalence of malaria in southern Formosa." Indian Journal of Malariology, no. 4: 471-486.

Watson R. B., Paul J. H. and Liang K. C. (1950). “A Report on One Year's Field Trial of Chlorguanide (Paludrine) as a Suppressive and as a Therapeutic Agent in Southern Taiwan (Formosa)." Journal of the National Malaria Society, 9, no. 1: $25-43$.

W ATt John (1992). A Friend in Deed: ABMAC and the Republic of China. 1937-1987. New York, ABMAC.

Wear Delese and Kuczewski Mark G. (2004). "The Professionalism Movement: Can We Pause?" The American Journal of Bioethics, vol. 4, no. 2: 1-10.

Williams Louis L. Jr. (1947). "The World Health Organization.” Southern Medicine Journal, no. 40: 66-72.

Williams Ralph Chester (1951). The United States Public Health Service, 1798-1950. Washington (D.C.), USPHS.

World Health Organization ed. (1958). First Ten Years of World Health Organization. Geneva, World Health Organization.

Wu Xiang 烏翔 (ed.) (1995). Guofang yixueyuan yuanshi 國防醫學院院史 (The History of National Defense Medical Center). Taipei, National Defense Medical Center. 
XIE Weiquan 謝維銓 (1995). NAMRU-2: Taida yiyuan xinjiu yixueyenjiu jiaoti de qiaoliang 臺大醫院新舊醫學研究交替的橋樑 (NAMRU-2: the bridge between the new and old medical researchers in the medical school of NTU). In Medical School of NTU (ed.), Taida yiyuan bainian huaijiu 台大醫院百年懷舊. Taipei, Medical School of NTU: 178-181.

XINGZHENGYUAN WEISHENGSHU 行政院衛生署 (ed.) (2003). Taiwan pu nue ji shi 台灣撲 瘧紀實 (The record of malaria eradication in Taiwan). Taipei, Xingzhengyuan weishengshu.

Yager Joseph A. (1988). Transforming Agriculture in Taiwan: The Experience of the Joint Commission on Rural Reconstruction. Ithaca, Cornell University Press.

YANG Cuihua 楊翠華 (2008). “Meiyun dui Taiwan de weisheng jihua yu yiliao tizhi zhi xingsu 美援對台灣的衛生計畫與醫療體制之形塑 (American aids to sharp public health projects and medical system in Taiwan).” Bulletin of the Institute of Modern History, vol. 62: 93-139.

YeH Shu 葉曙 (1989). Xienhua taida sishinian 閒話台大四十年 (Talk on forty years in $N T U)$. Taipei, Zhuanji wenxue.

YIN Qian 尹倩 (2008). “Fenhua he ronghe: lun minguo yishituanti de fazhan tedian 分化和融合:論民國醫師團體的發展特點 (Separation and fusion: on the characteristics of medical doctor's group during the Republic period)." Gansu Shehui kexue (Gansu Social Science), no. 2.

YIP Ka-che (1982). "Health and Society in China: Public Health Education for the Community, 1912-1937.” Social Science \& Medicine, vol. 16, no. 12: 1197-1205.

YIP Ka-che (1995). Health and National Reconstruction in Nationalist China: The Development of Modern Health Services. 1928-1937. Ann Arbor (Mich.), Association for Asian Studies.

YIP Ka-Che (ed.) (2009). Disease, Colonialism, and the State: Malaria in Modern East Asian History. Hong Kong, Hong Kong University Press.

ZHANG Jian-qiu 張建俅 (2001). "Kangzhan shiqi zhandi jiuhu tixi de jiangou ji qi yunzuo: yi Zhongguo hongshizihui jiuhu zongdui wei zhongxin de tantao 抗戰 時期戰地救護體系的建構及其運作一以中國紅十字會救護總隊為中心的探 討 (The Field First Aid System During the Sino-Japanese War - The Medical Relief Corps of the China Red Cross)." Bulletin of the Institute of Modern History, Academia Sinica, no. 36: 117-165.

ZhANG Pengyuan 張朋園 and Luo Jiurong 羅久蓉 (1993). Zhou Meiyu xiansheng fangwen jilu 周美玉先生訪問紀錄 (Interview with General Zhou Meiyu). Taipei, Institute of Modern History, Academia Sinica.

ZhANG Zhi-jie 張之傑 (July, 2000). “Zhongguo sheng li xue zhi fu: Lin Ke-sheng 中 國生理學之父：林可勝” (The father of physiology in China: Lin Ke-sheng). Science Monthly 科學月刊, no. 367: 616-622.

ZHAO Jichang 趙既昌 (1985). Meiyun de yunyong 美援的運用 (The application of US aids). Taipei, Lienjing.

ZHongGuo GuOMINDANG ZHONGYANG WEIYUANHuI (ed.) (1981) 中國國民黨中央委員會 黨史會編. Zhonghua minguo zhongyao shiliao chubian: dui Ri kangzhan shiqi 中華民國重要史料初編一對日抗戰時期 (The primary archives of Republic of 
China: the period of anti-Japanese war). Taipei, Zhongguo Guomindang dangshi weiyuanhui.

ZHONGHUA MinguO WAIJIAO WENTI YANJIUHUI (ed.) 中華民國外交問題研究會編 (1965).

“Rijun qinfan Shanghai yu jinggong Huabei 日軍侵犯上海與進攻華北 (Japanese military invasion to Shanghai and Northern China)." Zhong-Ri waijiao shilaio congbain, vol. 3 中日外交史料叢編（三） (The collection of Sino-Japanese diplomatic archives, vol. 3). Taipei, Zhonghua min guo waijiao wenti yanjiuhui.

ZhuANG Rong-hui 莊榮輝 (2000). “'Shi qu Zhongguo?' Jianjie Meiguo waijiao shijia you guan Dulumen zhengfu dui Zhongguo neizhan zhengce zhi lundian" $\ulcorner$ 失去中國?」簡介美國外交史家有關杜魯門政府對中國內戰政策之論點 ("Loosing China? Short Presentation of Arguments by American Historians of Foreign Relations on Truman Government's Policies about Chinese Civil War") Jindai Zhongguo 近代中國, no. 138: 133-156.

ZHUANG Yong-ming 莊永明 (1998). Taiwan yiliao shi: yi taida yiyuan wei zhu zhou 台灣醫療史一一台大醫院為主軸 (Taiwan's history of medicine: focuing on NTU hospital). Taipei, Yuan liu chubanshe. 